\title{
Effect of different sources of potassium on yield and quality of apple (cv. Red Delicious) in temperate conditions
}

\author{
Showket Yousuf \\ Division of Soil Science, Faculty of Agriculture, SKUAST-K, Shalimar (J\&K), India \\ Muzamil Ahmad Sheikh* \\ Division of Fruit Science, Faculty of Horticulture, SKUAST-K, Shalimar (J\&K), India \\ Subhash Chand \\ Division of Soil Science, Faculty of Agriculture, SKUAST-K, Shalimar (J\&K), India \\ Jasra Anjum \\ School of Studies in Botany, Jiwaji University, Gwalior (Madhya Pradesh), India \\ *Corresponding author. E-mail: muzamiljabbar11@gmail.com
}

\begin{abstract}
The present investigation was carried out to observe the effect of potassium on different parameters of apple in temperate conditions. Randomized block design experiment was adapted for an orchard of 15 years old with collection of soil samples and their analysis for physico-chemical properties under different treatments with fixed quantity of urea $\left(1500 \mathrm{~g} /\right.$ tree), DAP $\left(750 \mathrm{~g} /\right.$ tree) and potassium through MOP, $\mathrm{K}_{2} \mathrm{SO}_{4}$ and $\mathrm{K}$-Schoenite $(2500 \mathrm{~g} /$ tree $)$ in three, one and two split applications, respectively. The first application of recommended quantity of fertilizers was applied three weeks before expected bloom, Second three weeks after fruit set and third application at the end of July. Sample collection was done in the month of September followed by analysis for different parameters and results revealed that application of potassium through MOP @ 2500g/tree with two foliar applications of MOP @ $1.5 \%$ including vermicompost @ $5 \mathrm{~kg} /$ tree $\left(\mathrm{T}_{4}\right)$ improved soil physical conditions, nutrient availability, fruit yield and quality of apple. The combined effect of chemical fertilizer, two sprays and organic fertilizer (vermicompost) showed significantly $(P \leq 0.05)$ higher results of nitrogen, phosphorous, potassium magnesium and sulphur but low calcium than other vermicompost added treatments. The work concluded that different potassium sources can have great impact on yield and quality of apple and respond to level of concentrations or dose as applied in current study with different split.
\end{abstract}

Keywords: Apple, Potassium, Quality, Vermicompost, Yield

\section{INTRODUCTION}

Apple is one of the oldest fruit known to mankind found in most temperate parts of the world and cooler hills of sub-tropical region. In India, Jammu and Kashmir, Himachal Pradesh and Uttarkhand has a significant position for this golden crop. Jammu and Kashmir has a major contribution in horticulture map of the country with about $1,43,534$ hectares of land under apple cultivation with the total annual production of $16,33,349$ MT (Anonymous, 2014). The production and productivity is comparatively low as compared to the USA, Europe, Australia and even China i.e. 30MT per hectare (Wani et al., 2014). Apple cultivation in Kashmir was confined only in Karewas and Kandi areas but now, the farmers have started growing apple in low land areas which causes inferior quality of apples due to low fertility of soils and less or no application of mineral fertilizer in general and potassium in particular (Najar et al., 2009). According to the nutritional point of view a

\section{Article Info}

DOI:10.31018/jans.v10i4.1945 Received: November 11, 2018 Revised: November 26, 2018 Accepted: November 30, 2018

\section{How to Cite}

Yousuf, S. et al. (2018). Effect of different sources of potassium on yield and quality of apple (cv. Red Delicious) in temperate conditions. Journal of Applied and Natural Science, 10(4): 1332-1340 good quality apple fruit contains appreciable quantity of sorbitol, sugars (sucrose, glucose and fructose), organic acids (mainly malic and caproic acids) and vitamins. The percentage composition of various ingredients from apple fruit is water 85.0 per cent, carbohydrates/sugars 2.6 per cent, dietary fibers 2.4 per cent, fat 0.2 per cent, proteins 0.32 per cent, vitamins A 0.1 per cent, vitamin C 8.0 per cent, vitamin $B_{1}$ (Thiamine) 1.0 per cent, vitamin $B_{3}$ (Niacin) 1.0 per cent, vitamin $B_{6}$ (Pyridoxin) 1.0 per cent, vitamin $\mathrm{B}_{9}$ (folic acid) 1.0 per cent, potassium 2.0 per cent, calcium 1.0 per cent, magnesium 1.0 per cent, iron 1.0 per cent, zinc 0.1 per cent and phosphorous 2.0 per cent (Anonymous, 2009).

The role of potassium in fruit production is often under estimated in comparison to nitrogen, as nitrogen is more eye catching while potassium is a silent performer and essential for the growth and development of plants, as it activates more than 60 enzymes which directly or indirectly involved in 
all major plant processes including $\mathrm{CO}_{2}$ assimilation, ATP synthesis, photosynthesis (Haeder and Mengel, 1976). Osmoregulation, transpiration, regulation of cellular $\mathrm{pH}$, Cation anion balance, etc, also provides strength to plant cell walls by assisting the processes like lignifications, increases leaf area and leaf chlorophyll content, delay leaf senescence, helps in translocation of carbohydrates and assimilation of nitrogen into amino acid and hence useful in protein synthesis. As far as potassium dynamics is concerned in soils, it exists in different forms viz. water soluble, exchangeable, non-exchangeable and lattice potassium. The water soluble and exchangeable together constitutes the plant available potassium (Mishra et al., 1993). The different forms of soil potassium are in dynamic equilibrium and any depletion is likely to shift equilibrium in the direction to replenish it (Ramamoorthy and Paliwal, 1976). (Singh et al. 1993) reported high correlations among different forms of potassium in Indian soils. Potassium a component of several minerals is released to soluble and exchangeable forms by weathering of the minerals (Huang, 1977). The relationship between different forms of potassium and release characteristic depends on soil mineralogy are well known (Bhonsle et al., 1992). Potassium improves both quality as well as quantity of fruit crops thus often described as a quality element for fruit production besides it improves juice content, vitamin $\mathrm{C}$, uniformity and acceleration of ripening of fruits, resistance to disease, bruising and physical damage during shipping and storage thus improves shelf life (Awasthi et al., 1993). The objective of the current study was to determine the effect of potassium on yield and quality of apple in temperate conditions.

\section{MATERIALS AND METHODS}

During the current study, standard methodology was adapted for estimation of different parameters which are described as under:

Leaf analysis: Collection and processing of apple leaf and fruit samples was done followed by digestion in diacid mixture of nitric acid perchloric acid in the ratio of 10: 4 . The digest was dissolved in double distilled water and filtered in $100 \mathrm{ml}$ volumetric flask. The filterate was analyzed for following elements.

Total nitrogen: Plant material $(0.5 \mathrm{~g})$ was digested in concentrated $\mathrm{H}_{2} \mathrm{SO}_{4}$ with digestion mixture consisting $\mathrm{K}_{2} \mathrm{SO}_{4}, \mathrm{CuSO}_{4}$, Se and $\mathrm{HgO}$. After digestion, the extract obtained was analyzed for total nitrogen using a micro-kjeldhal assembly according to procedure outlined by Jackson (1973).

Total phosphorous and potassium: The plant samples were digested using di acid $\left(3 \mathrm{HNO}_{3}\right.$ : 1 $\mathrm{HClO}_{4}$ ) according to the procedure detailed by Piper (1966). The $P$ in the digest was estimated spectro-photometrically by Vanado-Molybdophosphoric acid method (Sparks et al., 1996) and $\mathrm{K}$ content was analyzed with the help of flame photometer (Pratt, 1982).

Calcium and magnesium: The calcium and magnesium were estimated by Versenate method as described by Jackson (1973).

Total sulphur: The sulfur in plant materials is determined by digestion with Nitric and Perchloric acid (Blanchar et al., 1965).

Physical parameters: Weight of each fruit was recorded with the help of electronic balance and measured in grams with firmness determined by Zies Penetrometer by puncturing at three different places on its surface, after removing about one $\mathrm{sq}$. inch of the peel. Firmness was recorded in $\mathrm{lb}$ inch ${ }^{-2}$ and all the values obtained were averaged. Colour intensity was measured by comparing the coloured surface of fruit with the colour chart and expressed in percent. Fruit length and diameter was determined by picking four fruits from each treated unit for with the help of vernier calipers. Similarly fruit yield was recorded as total fruits harvested in $\mathrm{kg} /$ plant.

\section{Chemical parameters}

Total soluble solids (TSS): The TSS content was directly read on Zeis's hand refractrometer by putting a drop of fruit juice on prism and reading as Brix $^{\circ}$ at $20^{\circ} \mathrm{C}$ (A.O.A.C., 1980).

Percent acidity: Acidity of collected and processed fruit was determined by diluting a known volume of fruit juice and titrating against $0.1 \mathrm{~N}$ sodium hydroxide solutions, using phenolphthalein as an indicator, and expressed as percent of malic acid.

Juice content (\%): The content of juice was measured by pressing out juice from a known pulp weight with the help of a laboratory model basket press. The quantity of the juice obtained was expressed as a percent of pulp ( $/ / w)$ by using formula.

Juice content $=$ volume of juice $(\mathrm{ml}) /$ weight of pulp $(\mathrm{g}) \times 100$ .......Eq. 1

Organoleptic evaluation: The random sampling of fruit from each treatment was taken and was used for sensory evaluation of a penal of four judges on the basis of external appearance of fruit colour, taste, firmness, aroma, flesh colour, skin colour, fruit texture etc. A five point hedonic scale was used for evaluation. Fruit scoring 5, 4, 3, 2 and 1 were considered to be excellent, very good, good, fair and poor in quality.

Statistical analysis: The data collected on various parameters during investigation was statistically processed and analyzed as per the standard procedures. Simple coefficient of correlation ( $r$ ) was worked out between nutrient content of plants as per procedure outlined by Gomez and Gomez (1984) using "MINITAB and R" statistical software's. 


\section{RESULTS}

Effect of different sources of potassium on leaf nutrient content of apple: The data pertaining to the effect of different sources of potassium on leaf nutrient content of apple is presented under following headings.

Effect on nitrogen content of leaves: The statistical analysis of data revealed that the effect of different sources of potassium was not found significant on leaf nitrogen content, while as the interaction, effect different sources of potassium was found to be significant at $(P \leq 0.05)$. The nitrogen content of leaves ranged from 1.77 to 2.19 per cent with a mean value of 1.96 per cent. Lowest concentration of 1.77 per cent was found in control while as highest concentration of nitrogen was found in treatment $\mathrm{T}_{4}\left(\mathrm{RFQ}_{1}+2\right.$ foliar sprays of MOP@ 1.5\% + vermicompost @ 5 kg/tree) followed by 2.15 per cent from treatment $\mathrm{T}_{7}\left(\mathrm{RFQ}_{2}+\right.$ 2 sprays of $\mathrm{K}_{2} \mathrm{SO}_{4} @ 1.5 \%$ + vermicompost @ 5 $\mathrm{kg} /$ tree) and 2.10 per cent from treatment $\mathrm{T}_{10}$ $\left(\mathrm{RFQ}_{3}+2\right.$ sprays k-Schoenite @ 1.5\%+ vermicompost @ $5 \mathrm{~kg} / \mathrm{tree})$. However, the effect of vermicompost treated units was non-significant but slight significant variation with other treat- ments without vermicompost and control(Table 1). Effect on phosphorous content of leaves: The phosphorous content of leaves ranged from 0.15 to 0.33 per cent with a mean value of 0.21 per cent. The lowest phosphorous content of 0.15 per cent was found in control while as maximum content of 0.33 per cent found in treatment $T_{4}\left(R_{F} Q_{1}+\right.$ 2 foliar sprays of MOP@ 1.5\% + vermicompost @ $5 \mathrm{~kg} /$ tree) followed by 0.31 per cent from treatment $\mathrm{T}_{7}\left(\mathrm{RFQ}_{2}+2\right.$ sprays of $\mathrm{K}_{2} \mathrm{SO}_{4} @ 1.5 \%$ + vermicompost @ $5 \mathrm{~kg} /$ tree) and 0.29 per cent from $\mathrm{T}_{10}\left(\mathrm{RFQ}_{3}+2\right.$ sprays k-Schoenite @ 1.5\% + vermicompost @ 5 kg/tree). The effect of vermicompost added treatments showed statistically significant variation $(P \leq 0.05)$ over the other treatments without vermicompost and control(Table 1).

Effect on potassium content of leaves: The analysis of variance of the data pertaining to potassium content revealed that the effect of different sources of potassium significantly increased the potassium content of leaves (Table 1). The interaction effect of chemical fertilizer, foliar spray of potassium and vermicompost was found to be significant at $(P \leq 0.05)$. The highest content of 1.70 per cent in leaves was found from treatment $T_{4}\left(R F Q_{1}\right.$

Table 1. Effect of different sources of potassium on leaf nutrient content of apple.

\begin{tabular}{|c|c|c|c|c|c|c|c|}
\hline \multirow{2}{*}{\multicolumn{2}{|c|}{ Treatments }} & \multicolumn{6}{|c|}{ Nutrient content (\%) } \\
\hline & & \multirow{2}{*}{$\begin{array}{c}\mathbf{N} \\
1.77\end{array}$} & \multirow{2}{*}{$\begin{array}{c}\mathbf{P} \\
0.15\end{array}$} & \multirow{2}{*}{$\begin{array}{c}\mathbf{K} \\
1.17\end{array}$} & \multirow{2}{*}{$\begin{array}{c}\mathbf{C a} \\
1.42\end{array}$} & \multirow{2}{*}{$\begin{array}{c}\text { Mg } \\
0.23\end{array}$} & \multirow{2}{*}{$\begin{array}{c}\mathbf{S} \\
0.13\end{array}$} \\
\hline $\mathrm{T}_{1}$ & (Control) & & & & & & \\
\hline $\mathrm{T}_{2}$ & $\left(\mathrm{RFQ}_{1}\right)$ & 1.90 & 0.21 & 1.55 & 1.39 & 0.24 & 0.15 \\
\hline $\mathrm{T}_{3}$ & $\left(\mathrm{RFQ}_{1}+2\right.$ sprays of MOP @ $\left.1.5 \%\right)$ & 1.95 & 0.22 & 1.60 & 1.38 & 0.24 & 0.16 \\
\hline $\mathrm{T}_{4}$ & $\left(R F Q_{1}+2\right.$ sprays of MOP @ $\left.1.5 \%+V C\right)$ & 2.19 & 0.33 & 1.70 & 1.35 & 0.30 & 0.23 \\
\hline $\mathrm{T}_{5}$ & $\left(\mathrm{RFQ}_{2}\right)$ & 1.89 & 0.20 & 1.52 & 1.39 & 0.26 & 0.17 \\
\hline $\mathrm{T}_{6}$ & $\left(\mathrm{RFQ}_{2}+2\right.$ sprays of $\left.\mathrm{K}_{2} \mathrm{SO}_{4} @ 1.5 \%\right)$ & 1.92 & 0.21 & 1.53 & 1.38 & 0.27 & 0.18 \\
\hline $\mathrm{T}_{7}$ & $\left(\mathrm{RFQ}_{2}+2\right.$ sprays of $\left.\mathrm{K}_{2} \mathrm{SO}_{4} @ 1.5 \%+\mathrm{VC}\right)$ & 2.15 & 0.31 & 1.69 & 1.36 & 0.34 & 0.24 \\
\hline $\mathrm{T}_{8}$ & $\left(\mathrm{RFQ}_{3}\right)$ & 1.86 & 0.19 & 1.19 & 1.40 & 0.27 & 0.20 \\
\hline $\mathrm{T}_{9}$ & $\left(\mathrm{RFQ}_{3}+2\right.$ sprays of K-Schoenite @ 1.5\%) & 1.88 & 0.20 & 1.50 & 1.39 & 0.28 & 0.22 \\
\hline \multirow[t]{2}{*}{$\mathrm{T}_{10}$} & $\left(\mathrm{RFQ}_{3}+2\right.$ sprays of K-Schoenite @ $\left.1.5 \%+\mathrm{VC}\right)$ & 2.10 & 0.29 & 1.66 & 1.36 & 0.35 & 0.25 \\
\hline & $\mathrm{CD}(\mathrm{P} \leq 0.05)$ & 0.029 & 0.025 & 0.039 & 0.012 & 0.025 & 0.025 \\
\hline
\end{tabular}

$\mathrm{RFQ}_{1}=$ Recommended fertilizer quantity of Urea, DAP and MOP; RFQ $=$ Recommended fertilizer quantity of Urea, DAP and $\mathrm{K}_{2} \mathrm{SO}_{4} ; \mathrm{RFQ}_{3}=$ Recommended fertilizer quantity of Urea, DAP and K-Schoenite.

Table 2. Sources of potassium and fruit characteristics under different treatments.

\begin{tabular}{|c|c|c|c|c|c|c|}
\hline \multirow{2}{*}{\multicolumn{2}{|c|}{ Treatments }} & \multicolumn{5}{|c|}{ Fruit characteristics } \\
\hline & & \multirow{2}{*}{$\begin{array}{c}\begin{array}{c}\text { Weight } \\
\text { (g) }\end{array} \\
194.1\end{array}$} & \multirow{2}{*}{$\begin{array}{c}\begin{array}{c}\text { Length } \\
\text { (cm) }\end{array} \\
5.3\end{array}$} & \multirow{2}{*}{$\begin{array}{c}\begin{array}{c}\text { Diameter } \\
\text { (cm) }\end{array} \\
5.7\end{array}$} & \multirow{2}{*}{$\begin{array}{c}\begin{array}{c}\text { Firmness } \\
\text { (lb inch }^{-2} \text { ) }\end{array} \\
16.9\end{array}$} & \multirow{2}{*}{$\begin{array}{c}\begin{array}{c}\text { Yield } \\
\text { (kg/tree) }\end{array} \\
53.2\end{array}$} \\
\hline & (Control) & & & & & \\
\hline $\mathrm{T}_{2}$ & $\left(\mathrm{RFQ}_{1}\right)$ & 210.1 & 6.1 & 6.5 & 16.0 & 60.5 \\
\hline $\mathrm{T}_{3}$ & $\left(R F Q_{1}+2\right.$ sprays of MOP @ $\left.1.5 \%\right)$ & 211.2 & 6.7 & 6.9 & 15.8 & 60.8 \\
\hline $\mathrm{T}_{4}$ & $\left(\mathrm{RFQ}_{1}+2\right.$ sprays of MOP @ $\left.1.5 \%+\mathrm{VC}\right)$ & 218.3 & 7.2 & 7.8 & 15.3 & 63.4 \\
\hline $\mathrm{T}_{5}$ & $\left(\mathrm{RFQ}_{2}\right)$ & 208.8 & 6.1 & 6.5 & 16.3 & 60.1 \\
\hline & $\left(\mathrm{RFQ}_{2}+2\right.$ sprays of $\left.\mathrm{K}_{2} \mathrm{SO}_{4} @ 1.5 \%\right)$ & 210.6 & 6.3 & 6.9 & 16.0 & 61.7 \\
\hline & $\left(\mathrm{RFQ}_{2}+2\right.$ sprays of $\left.\mathrm{K}_{2} \mathrm{SO}_{4} @ 1.5 \%+\mathrm{VC}\right)$ & 215.8 & 7.0 & 7.5 & 15.5 & 62.6 \\
\hline $\mathrm{T}_{8}$ & $\left(\mathrm{RFQ}_{3}\right)$ & 207.9 & 6.1 & 6.4 & 16.4 & 59.1 \\
\hline & $\left(\mathrm{RFQ}_{3}+2\right.$ sprays of K-Schoenite @ 1.5\%) & 209.2 & 6.2 & 6.9 & 16.1 & 60.6 \\
\hline & $\begin{array}{l}\left(\mathrm{RFQ}_{3}+2 \text { sprays of K-Schoenite @ 1.5\% + }\right. \\
\text { VC) }\end{array}$ & 214.1 & 7.0 & 7.6 & 15.6 & 62.2 \\
\hline & $\leq 0.05)$ & 2.853 & 0.545 & 0.984 & 1.052 & 0.762 \\
\hline
\end{tabular}

$\mathrm{RFQ}_{1}=$ Recommended fertilizer quantity of Urea, DAP and MOP; RFQ $=$ Recommended fertilizer quantity of Urea, DAP and $\mathrm{K}_{2} \mathrm{SO}_{4} ; \mathrm{RFQ}_{3}=$ Recommended fertilizer quantity of Urea, DAP and K-Schoenite. 
Table 3. Different sources of potassium and quality characteristics of fruit.

\begin{tabular}{|c|c|c|c|c|c|c|}
\hline \multirow{2}{*}{\multicolumn{2}{|c|}{ Treatments }} & \multicolumn{5}{|c|}{ Quality characteristics } \\
\hline & & \multirow{2}{*}{$\begin{array}{c}\begin{array}{c}\text { Colour } \\
(\%)\end{array} \\
53.6\end{array}$} & \multirow{2}{*}{$\begin{array}{c}\begin{array}{c}\text { TSS } \\
\text { ('Brix) }\end{array} \\
9.8\end{array}$} & \multirow{2}{*}{$\begin{array}{c}\begin{array}{c}\text { Acidity } \\
(\%)\end{array} \\
0.21\end{array}$} & \multirow{2}{*}{$\begin{array}{c}\begin{array}{c}\text { Juice } \\
\text { content } \\
(\%)\end{array} \\
32.6\end{array}$} & \multirow{2}{*}{$\begin{array}{c}\text { Organoleptic } \\
\text { rating (1-5) }\end{array}$} \\
\hline & (Control) & & & & & \\
\hline $\mathrm{T}_{2}$ & $\left(\mathrm{RFQ}_{1}\right)$ & 68.2 & 10.8 & 0.16 & 37.2 & 3.67 \\
\hline $\mathrm{T}_{3}$ & $\left(\mathrm{RFQ}_{1}+2\right.$ sprays of MOP @ $\left.1.5 \%\right)$ & 72.0 & 13.9 & 0.15 & 38.7 & 4.33 \\
\hline $\mathrm{T}_{4}$ & $\left(R F Q_{1}+2\right.$ sprays of MOP @ $\left.1.5 \%+V C\right)$ & 80.6 & 15.8 & 0.13 & 41.7 & 5.00 \\
\hline $\mathrm{T}_{5}$ & $\left(\mathrm{RFQ}_{2}\right)$ & 64.6 & 10.1 & 0.19 & 36.2 & 2.00 \\
\hline $\mathrm{T}_{6}$ & $\left(\mathrm{RFQ}_{2}+2\right.$ sprays of $\left.\mathrm{K}_{2} \mathrm{SO}_{4} @ 1.5 \%\right)$ & 65.2 & 13.7 & 0.17 & 37.9 & 3.33 \\
\hline & $\left(\mathrm{RFQ}_{2}+2\right.$ sprays of $\left.\mathrm{K}_{2} \mathrm{SO}_{4} @ 1.5 \%+\mathrm{VC}\right)$ & 77.2 & 14.2 & 0.14 & 41.2 & 4.67 \\
\hline & $\left(\mathrm{RFQ}_{3}\right)$ & 60.9 & 10.6 & 0.20 & 35.6 & 1.67 \\
\hline & $\left(\mathrm{RFQ}_{3}+2\right.$ sprays of K-Schoenite @ 1.5\%) & 62.5 & 13.5 & 0.18 & 37.6 & 2.67 \\
\hline & $\begin{array}{l}\left(\mathrm{RFQ}_{3}+2 \text { sprays of K-Schoenite @ } 1.5 \%\right. \\
+\mathrm{VC})\end{array}$ & 74.9 & 14.1 & 0.14 & 40.5 & 3.00 \\
\hline CD & $\leq 0.05)$ & 0.927 & 0.820 & 0.052 & 2.787 & 1.031 \\
\hline
\end{tabular}

$\mathrm{RFQ}_{1}=$ Recommended fertilizer quantity of Urea, DAP and MOP;RFQ $\mathrm{R}_{2}=$ Recommended fertilizer quantity of Urea, DAP and $\mathrm{K}_{2} \mathrm{SO}_{4} ; \mathrm{RFQ}_{3}=$ Recommended fertilizer quantity of Urea, DAP and K-Schoenite.

+ 2 foliar sprays of MOP@ $1.5 \%$ + vermicompost @ $5 \mathrm{~kg} /$ tree) followed by 1.69 per cent from $\mathrm{T}_{7}$ $\left(\mathrm{RFQ}_{2}+2\right.$ sprays of $\mathrm{K}_{2} \mathrm{SO}_{4} @ 1.5 \%$ + vermicompost @ $5 \mathrm{~kg} /$ tree) and 1.66 per cent from $\mathrm{T}_{10}$ $\left(\mathrm{RFQ}_{3}+2\right.$ sprays k-Schoenite @ 1.5\%+ Vermicompost @ 5 kg/tree) which was found higher than the $\mathrm{K}$ content obtained from treatments without vermicompost and control (1.17\%) (Table 1).

Effect on calcium of content of leaves: The data on calcium content of leaves revealed that the effect of different sources of potassium significantly decreased the Ca content (Table 1). There has been a significant decrease $(P \leq 0.05)$ with respect to their interaction effect also. The lowest content of calcium (1.35\%) was obtained with the treatment $\mathrm{T}_{4}\left(\mathrm{RFQ}_{1}+2\right.$ foliar sprays of MOP @ $1.5 \%$ + vermicompost @ 5 kg/tree) followed by 1.36 per cent from $\mathrm{T}_{7}\left(\mathrm{RFQ}_{2}+2\right.$ sprays of $\mathrm{K}_{2} \mathrm{SO}_{4}$ @ $1.5 \%$ + vermicompost @ 5 kg/tree) and 1.36 per cent from $\mathrm{T}_{10}\left(\mathrm{RFQ}_{3}+2\right.$ sprays k-Schoenite @ 1.5\%+vermicompost @ 5 kg/tree) which was found to be much less than control (1.42 \%) (Table 1).

Effect on magnesium content of leaves: The analysis of variance with respect to magnesium content in leaves revealed that there is a significant effect $(P \leq 0.05)$ of different sources of potassium along with vermicompost on leaf magnesium (Table 1). The lowest magnesium content of 0.23 per cent was found in control and the maximum content of leaf magnesium of 0.35 per cent was found treatment $\mathrm{T}_{10}\left(\mathrm{RFQ}_{3}+2\right.$ sprays k-Schoenite @ 1.5\%+Vermicompost @ 5 kg/tree) followed by 0.34 from $\mathrm{T}_{7}\left(\mathrm{RFQ}_{2}+2\right.$ sprays of $\mathrm{K}_{2} \mathrm{SO}_{4} @ 1.5 \%$ + vermicompost @ $5 \mathrm{~kg} /$ tree) and 0.30 from $\mathrm{T}_{4}$ $\left(R F Q_{1}+2\right.$ foliar sprays of MOP@1.5\% + vermicompost @ 5 kg/tree) (Table 1).

Effect on sulphur content of leaves: The sulphur content of leaves significantly increased from 0.13 to 0.25 per cent. The highest sulphur content of 0.25 per cent was found in treatment $T_{7}\left(R F Q_{2}\right.$
+2 sprays of $\mathrm{K}_{2} \mathrm{SO}_{4} @ 1.5 \%$ + vermicompost @ 5 $\mathrm{kg} /$ tree) followed by 0.24 per cent from $\mathrm{T}_{10}\left(\mathrm{RFQ}_{3}\right.$ + 2 sprays k-Schoenite @ 1.5\%+ vermicompost @ $5 \mathrm{~kg} /$ tree) and 0.23 per cent from $\mathrm{T}_{4}\left(\mathrm{RFQ}_{1}+2\right.$ foliar sprays of MOP@1.5\% + Vermicompost @ 5 $\mathrm{kg} /$ tree) which showed a significantly high over the control. The sulphur content of treatments without vermicompost was also found non-significant to each other but the interaction effect of chemical fertilizers, spray and vermicompost was found superior to all other the treatments and control (Table 1).

Effect of different sources of potassium on yield and quality: The data pertaining to the effect of different sources of potassium on fruit yield and quality is presented under different headings. The application of different sources of potassium along with vermicompost on fruit yields and quality markedly increased the yield and quality parameters of apple.

Effect on yield: The results revealed that there was progressively significant increase in fruit characteristics and yield. The fruit yield ranged from $53.2 \mathrm{~kg} /$ tree to $63.3 \mathrm{~kg} /$ tree and the maximum yield $63.3 \mathrm{~kg} /$ tree was obtained from the treatment $\mathrm{T}_{4}\left(\mathrm{RFQ}_{1}+2\right.$ foliar sprays of MOP@ $1.5 \%$ + vermicompost @ 5 kg/tree) followed by 62.6 kg/tree from $\mathrm{T}_{7}\left(\mathrm{RFQ}_{2}+2\right.$ sprays of $\mathrm{K}_{2} \mathrm{SO}_{4} @ 1.5 \%$ + vermicompost @ 5 kg/tree) and 62.2 kg/tree from $T_{10}$ $\left(\mathrm{RFQ}_{3}+2\right.$ sprays of $\mathrm{K}_{2} \mathrm{SO}_{4} @ 1.5 \%$ + vermicompost @ $5 \mathrm{~kg} /$ tree) and showed significant variation $(P \leq 0.05)$ over the control $(53.2 \mathrm{~kg} /$ tree) (Table 2$)$.

Effect on fruit dimensions: The data revealed that the fruit length and fruit diameter ranged from $5.3 \mathrm{~cm}$ to $7.1 \mathrm{~cm}$ and $5.7 \mathrm{~cm}$ to $7.8 \mathrm{~cm}$ respectively and maximum fruit length and fruit diameter of $7.1 \mathrm{~cm}$ and $7.8 \mathrm{~cm}$ was recorded from $\mathrm{T}_{4}\left(\mathrm{RFQ}_{1}+\right.$ 2 foliar sprays of MOP@ 1.5\% + vermicompost @ $5 \mathrm{~kg} /$ tree) followed by $7.0 \mathrm{~cm}$ and $7.5 \mathrm{~cm}$ from $\mathrm{T}_{7}$ $\left(\mathrm{RFQ}_{2}+2\right.$ sprays of $\mathrm{K}_{2} \mathrm{SO}_{4} @ 1.5 \%$ + vermicompost @ $5 \mathrm{~kg} /$ tree) and $7.0 \mathrm{~cm}$ and $7.6 \mathrm{~cm}$ fromT 10 
$\left(\mathrm{RFQ}_{3}+2\right.$ sprays of $\mathrm{K}_{2} \mathrm{SO}_{4} @ 1.5 \%$ + vermicompost @ $5 \mathrm{~kg} /$ tree) and showed significant variation $(\mathrm{P} \leq 0.05)$ over the other treatments and control (5.3 and $5.7 \mathrm{~cm}$ ) (Table 2).

Effect on fruit firmness: The results revealed that the fruit firmness followed a reverse trend and was ranged from 15.3 to $16.9 \mathrm{lb} \mathrm{inch}^{-2}$. The lowest fruit firmness of $15.3 \mathrm{lb}_{\text {inch }}^{-2}$ was recorded from the treatment $\mathrm{T}_{4}\left(\mathrm{RFQ}_{1}+2\right.$ foliar sprays of MOP@ $1.5 \%$ + vermicompost @ 5 kg/tree) followed by $15.5 \mathrm{lb}$ inch $^{-2}$ from treatment $\mathrm{T}_{7}\left(\mathrm{RFQ}_{2}+2\right.$ sprays of $\mathrm{K}_{2} \mathrm{SO}_{4} @ 1.5 \%$ + vermicompost @ 5 kg/tree) and $15.6 \mathrm{lb}$ inch $^{-2}$ from treatment $\mathrm{T}_{10}\left(\mathrm{RFQ}_{3}+2\right.$ sprays of $\mathrm{K}_{2} \mathrm{SO}_{4} @ 1.5 \%$ + vermicompost @ $5 \mathrm{~kg} /$ tree) and showed a significant difference $(P \leq 0.05)$ over other treatments and control $\left(16.9 \mathrm{lb} \mathrm{inch}^{-2}\right)$ (Table 2).

Effect on fruit weight: The results revealed that the fruit weight ranged from $194.1 \mathrm{~g}$ to $218.3 \mathrm{~g}$ and the highest fruit weight was recorded $218.3 \mathrm{~g}$ from treatment $\mathrm{T}_{4}\left(\mathrm{RFQ}_{1}+2\right.$ foliar sprays of MOP @ 1.5\% + vermicompost @ 5 kg/tree) followed by $215.8 \mathrm{~g}$ from treatment $\mathrm{T}_{7}\left(\mathrm{RFQ}_{2}+2\right.$ sprays of $\mathrm{K}_{2} \mathrm{SO}_{4} @ 1.5 \%$ + vermicompost @ 5 kg/tree) and $214.1 \mathrm{~g}$ from treatment $\mathrm{T}_{10}\left(\mathrm{RFQ}_{3}+2\right.$ sprays of $\mathrm{K}_{2} \mathrm{SO}_{4} @ 1.5 \%$ + vermicompost @ 5 kg/tree). However the treatment $\mathrm{T}_{4}$ showed significant variation $(P \leq 0.05)$ over other treatment combination without vermicompost and control (194.1 g) (Table 2).

Effect on fruit colour: The fruit colour of apple ranged from 47.6 to 80.6 per cent and highest fruit colour 80.6 per cent was observed in the treatment $\mathrm{T}_{4}\left(\mathrm{RFQ}_{1}+2\right.$ foliar sprays of MOP@ $1.5 \%$ + vermicompost @ 5 kg/tree) followed by 77.2 per cent from treatment $\mathrm{T}_{7}\left(\mathrm{RFQ}_{2}+2\right.$ sprays of $\mathrm{K}_{2} \mathrm{SO}_{4}$ @ 1.5\% + vermicompost @ 5 kg/tree) and 74.9 per cent from treatment $\mathrm{T}_{10}\left(\mathrm{RFQ}_{3}+2\right.$ sprays of $\mathrm{K}_{2} \mathrm{SO}_{4} @ 1.5 \%$ + vermicompost @ 5 kg/tree). The treatment $\mathrm{T}_{4}$ was found superior over the other treatments and control (53.6\%) (Table 3).

Effect on TSS: The results of TSS revealed that the total soluble solids (TSS) it ranged from 9.8 to 15.8 Brix $^{\circ}$ with a mean value of 12.6 Brix $^{\circ}$. The highest TSS $15.8\left(\mathrm{Brix}^{\circ}\right)$ was recorded from the treatment $\mathrm{T}_{4}\left(\mathrm{RFQ}_{1}+2\right.$ foliar sprays of MOP@ $1.5 \%$ + vermicompost @ 5 kg/tree) followed by $14.2{ }^{\circ} \mathrm{Brix}$ from the treatment $\mathrm{T}_{7}\left(\mathrm{RFQ}_{2}+2\right.$ sprays of $\mathrm{K}_{2} \mathrm{SO}_{4} @ 1.5 \%$ + vermicompost @ 5 kg/tree) and $14.1\left(\mathrm{Brix}^{\circ}\right)$ from the treatment $\mathrm{T}_{10}\left(\mathrm{RFQ}_{3}+2\right.$ sprays of $\mathrm{K}_{2} \mathrm{SO}_{4} @ 1.5 \%$ + vermicompost @ 5 kg/ tree) and was found to be superior than rest of treatments and control (9.8 Brix $\left.^{\circ}\right)$ (Table 3).

Effect on juice content: The juice content in apple ranged from 32.6 to 41.7 per cent with a mean value of 37.9 per cent and the maximum juice of 41.7 per cent content was recorded from the treatment $\mathrm{T}_{4}\left(\mathrm{RFQ}_{1}+2\right.$ foliar sprays of MOP@ $1.5 \%+$ vermicompost @ 5 kg/tree) followed by 41.2 per cent from the treatment $T_{7}\left(R_{F} Q_{2}+2\right.$ sprays of
$\mathrm{K}_{2} \mathrm{SO}_{4} @ 1.5 \%$ + vermicompost @ 5 kg/tree) and 40.5 per cent from the treatment $\mathrm{T}_{10}\left(\mathrm{RFQ}_{3}+2\right.$ sprays of $\mathrm{K}_{2} \mathrm{SO}_{4} @ 1.5 \%$ + vermicompost @ $5 \mathrm{~kg} /$ tree) which found significant $(\mathrm{P} \leq 0.05)$ over all other the treatments and control (32.6\%)(Table 3). Effect on fruit acidity: The data revealed that the fruit acidity showed reverse trend and ranged from 0.21 to 0.13 per cent with a mean value of 0.16 per cent. The lowest fruit acidity 0.13 per cent was recorded from the treatment $\mathrm{T}_{4}\left(\mathrm{RFQ}_{1}+2\right.$ foliar sprays of MOP@1.5\% + vermicompost @ 5 kg/ tree) followed by 0.14 per cent from the treatment $\mathrm{T}_{7}\left(\mathrm{RFQ}_{2}+2\right.$ sprays of $\mathrm{K}_{2} \mathrm{SO}_{4} @ 1.5 \%$ + vermicompost @ $5 \mathrm{~kg} /$ tree) and 0.14 per cent from the treatment $\mathrm{T}_{10}\left(\mathrm{RFQ}_{3}+2\right.$ sprays of $\mathrm{K}_{2} \mathrm{SO}_{4} @$ $1.5 \%$ + vermicompost @ 5 kg/tree) and was found significant $(P \leq 0.05)$ over other treatments without vermicompost and control $(0.21 \%$ ) (Table 3$)$.

Organoleptic evaluation: The Organoleptic rating of apple ranged from 1.33 to 5.00 with a mean value of 3.16 (Table 3 ). The highest organoleptic rating of 5.00 was recorded from treatment $\mathrm{T}_{4}$ $\left(\mathrm{RFQ}_{1}+2\right.$ foliar sprays of MOP@ $1.5 \%$ + vermicompost @ $5 \mathrm{~kg} /$ tree) followed by 4.67 from treatment $\mathrm{T}_{7}\left(\mathrm{RFQ}_{2}+2\right.$ sprays of $\mathrm{K}_{2} \mathrm{SO}_{4} @ 1.5 \%$ + vermicompost @ 5 kg/tree) and 3.0 from treatment $\mathrm{T}_{10}\left(\mathrm{RFQ}_{3}+2\right.$ sprays of $\mathrm{K}_{2} \mathrm{SO}_{4} @ 1.5 \%+$ vermicompost @ 5 kg/tree) and found superior than rest of the treatment and control (1.33) (Table 3).

\section{DISCUSSION}

The results obtained on effect of different sources of potassium on fruit yield and quality of apple on leaf nutrient content is discussed under the following headings.

Effect on nitrogen content of leaves: The results revealed that nitrogen content of leaves was slightly increased with the application different sources of potassium from $T_{1}$ to $T_{10}$. The maximum nitrogen content was found in $\mathrm{T}_{4}(2.19 \%)$ followed by $\mathrm{T}_{7}(2.15 \%)$ and $\mathrm{T}_{10}(2.10 \%)$. However the effect was found non- significant. The treatments in which vermicompost was added in combination to different sources of potassium showed a significant variation $(P \leq 0.05)$ with vermicompost treated combination. These finding are in close conformity with the results obtained by Awasthi et al. (1993) were they worked on Santa rosa plum and showed increment in both yield and quality. Similar results were also later on observed by Anjum (2008) while working on apple.

Effect on phosphorous content of leaves: A significant increase in the phosphorous content of leaves was observed from the treatment $T_{1}$ to $T_{10}$. The highest phosphorous content was recorded in the treatment $\mathrm{T}_{4}(0.33 \%)$ followed by $\mathrm{T}_{7}(0.31 \%)$ and $\mathrm{T}_{10}(0.29 \%)$ but the effect was non-significant to each other and significant over other combinations. Similar results were obtained by Awasthi et 
al. (1993) and Kaith et al. (1998) while studying plum and apple orchard soils of Himachal Pradesh.

Effect on potassium content of leaves: The results revealed that $\mathrm{K}$ content of leaves got significantly increased from 1.17 to 1.70 per cent. The maximum $\mathrm{K}$ content in leaves was found in $\mathrm{T}_{4}$ followed by $T_{7}$ and $T_{10}$ and showed a slight significant variation over other treatment combinations and control.

Increase in the concentration of potassium in leaves with different sources of potassium in combination with organic manure (vermicompost) is due to the fact that plants go on absorbing $\mathrm{K}$, known as luxury level (Simith, 1962), so more we give more it will take. Similar results were obtained by Kaith and Awasthi (1998); Awasthi et al. (1993); Singh et al. (2009) and Hudina et al. (2002) and later on by Anjum et al. (2008).

Further with the foliar application of $\mathrm{K}$ in treatment combinations (no vermicompost) (foliar spray @ $1.5 \%$ of different sources of potassium) also significantly increased $\mathrm{K}$ in leaves. This may be due to direct absorption of potassium through leaves. The results are in agreement with the finding of Hudina et al. (2002) while working on pear and Awasthi et al. (1993) on plum.

Effect on calcium content of leaves: The results showed a slightly significant decrease in the calcium content of leaves from 1.42 to 1.35 per cent with the application of different sources of potassium in various treatments combinations. The increase (variation) in potassium $\left(\mathrm{K}_{2} \mathrm{O}\right)$ application through different sources along with vermicompost in soil, increases the ionic activity of $\mathrm{K}^{+}$in soil solution with simultaneous decrease in activity of $\mathrm{Ca}^{2+}$ ions results in its decreased absorption by plant roots. Thus increase in $\mathrm{K}^{+}$concentration results in simultaneous decrease in $\mathrm{Ca}^{2+}$ uptake (Oberly and Kenworthy, 1961). The slight decrease in calcium was also observed in other treatments (no vermicompost). The greater decrease in calcium was observed in the treatments $T_{4}$ followed by $T_{7}$ and $T_{10}$. Thus increasing $K_{2} O$ in MOP (recommended dose) and foliar application of same source @ 1.5\% than other potassium sources was found safe as far as $\mathrm{Ca}^{2+}$ concentration in leaves is concerned. Similar results were reported by Dev et al. (1995) and Dias and Flore (2002) while working on apple vegetation.

Effect on magnesium content of leaves: The results revealed that the magnesium content of leaves was higher in treatment $\mathrm{T}_{10}(0.35 \%)$ followed by $\mathrm{T}_{7}(0.34 \%)$ and $\mathrm{T}_{4}(0.30 \%)$. The increase in magnesium content of leaves in $\mathrm{T}_{10}$ was due to that potassium Schoenite $\left(\mathrm{K}_{2} \mathrm{SO}_{4} \mathrm{MgSO}_{4}\right)$ contains magnesium as an ingredient in its composition which enhanced the available soil magnesium influenced the more uptake through roots while as foliar application of same fertilizers also influences the absorption through leaves. The results are in accordance with Chand et al. (2009) while working on mustard.

Effect on sulphur content of leaves: The data revealed that the sulphur content of leaves was higher in treatment $\mathrm{T}_{7}(0.25 \%)$ followed by $\mathrm{T}_{10}$ $(0.24 \%)$ and $\mathrm{T}_{4}(0.23 \%)$. The decrease in sulphur content of leaves in $\mathrm{T}_{4}$ was due to that MOP does not contain sulphur while as the other sources contain sulphur in potassium sources and sulphur content in descending order in potassium sources are $\mathrm{K}_{2} \mathrm{SO}_{4}>\mathrm{K}_{2} \mathrm{SO}_{4} \mathrm{MgO}>\mathrm{MOP}$ (no sulphur) (Table 1). However the effect was non-significant. Similar results were noticed from Kaith et al. (2010) and Dev et al. (1995) both showed nutrient status while worked on apple.

Effect of different sources of potassium yield and quality: Effect of different sources of potassium on fruit yield and quality of apple are discussed under the following heading.

Effect on fruit weight and fruit dimensions (length and diameter): The results revealed that there was a slight difference in fruit weight, length as well as diameter of apple in treatment combinations of $T_{4}, T_{7}$ and $T_{10}$. The highest fruit weight, length and diameter of $218.3 \mathrm{~g}, 7.2 \mathrm{~cm}$ and $7.8 \mathrm{~cm}$ respectively was recorded from treatment $T_{4}$ followed by treatment $T_{7}$ and $T_{10}$ but showed a nonsignificant effect with each other. The other treatments in which vermicompost were not added in combination showed a significant variation over $T_{4}, T_{7}$ and $T_{10}$. The increase in fruit weight, length as well as diameter may be attributed to higher cell division and photosynthetic activities. Photosynthetates are supplied to fruits by leaves on account of K-fertilization (Hansen, 1970). Further with the application of foliar $\mathrm{K}$ (through different sources)@1.5 per cent and vermicompost @ 5 $\mathrm{kg} /$ tree showed significant increase $(P \leq 0.05)$ in fruit weight as well as in size. Similar observations were recorded by Doroshenko et al. (2005). When they recorded a significant increase in fruit market qualities, fruit size as well as yield on applying foliar spray of K2SO4@ 0.3 per cent. Similar results were also obtained by Kilany and Kilany (1991).

Effect on fruit firmness: The results revealed an increase in fruit firmness with the application of different sources of potassium. The lowest fruit firmness of $15.3 \mathrm{lb}$ inch $^{-2}$ was recorded in treatment $T_{4}$ followed by $T_{7}$ and $T_{10}$. Decrease in fruit firmness with increase in $\mathrm{K}$ application both in soil and spray @ 1.5\% in addition to organic manures (vermicompost) was also reported by Kilany and Kilany (1991); Naiema (2003) and Wojcik (2005) while working on apple varieties. Also it was observed that with the increase in soil potassium ( $\mathrm{K}_{2} \mathrm{O}$ content) through $\mathrm{T}_{4}$, the fruit firmness got decreased, this may be due to the fact that calcium content of fruit sharply decrease due to in- 
creased potassium application. As calcium is an important constituent of cell wall, thus very low concentration of $\mathrm{Ca}^{2+}$ will definitely tell upon cell wall formation, hence on fruit firmness.

Effect on fruit yield: The results revealed that fruit yield got significantly increased in $T_{4}, T_{7}$ and $\mathrm{T}_{10}$. The maximum fruit yield of $63.4 \mathrm{~kg} /$ tree was found in $T_{4}$ which showed slight increase over $T_{7}$ and $T_{10}$ but the effect was non- significant. The higher yield was due to the maximum no of bud burst and maximum flower retention and strong petiole formation which prevents the early fruit drops and also minimizes the moisture stress during fruit development stages, hence enhance the yield. Similar results were reported by Cuming (1980); Kaith and Awasthi (1989) and Nabi et al. 2018 on apple trees and Hafeez et al. (2010) on plum plantation.

Effect on fruit TSS: The result revealed that fruit TSS got significantly increased from 9.8 to 15.8 $\left(B\right.$ Bix $\left.^{\circ}\right)$ with different sources of potassium from $T_{1}$ to $T_{10}$. The highest fruit TSS was found in $T_{4}$ treatment combination while as the treatment $T_{7}$ and $\mathrm{T}_{10}$ was statistically at par with each other but all the vermicompost treated combination showed a significant variation over all the treatment and control. Potassium uptake is expected to assist in $\mathrm{CO}_{2}$ assimilation and subsequent synthesis of carbohydrates which was probably higher on account of increased potassium fertilization. Thus increase the fruit TSS significantly. These results were in close conformity with those obtained by Kaith and Awasthi (1989); Daroshenko et al. (2005) and Wojcik (2005) while working on different cultivars of apple.

Effect on fruit acidity: Fruit acidity as per results showed decreasing trend with different sources of potassium application because of variation in $\mathrm{K}_{2} \mathrm{O}$ content. The lowest fruit acidity of 0.13 per cent was found in treatment combination of $\mathrm{T}_{4}$ followed by $T_{7}$ and $T_{10}$. The decrease in fruit acidity is believed due to the enhanced maturity of fruits. It was reported that potassium application enhanced the fruit maturity, by directly affecting the enzymatic activity of cells (Barden and Thompson, 1962). The results are supported by the findings of Kaith and Awasthi (1989) and Naiema (2003) and later on by Anjum et al. (2008) while working on apple plants.

Effect on fruit colour: Significant increase in fruit colour from 47.6 to 80.6 percent with the application of different sources of potassium and the maximum fruit colour was recorded in treatment combination of $\mathrm{T}_{4}(80.6 \%)$ while the treatment combination $\mathrm{T}_{7}$ and $\mathrm{T}_{10}$ showed a non-significant with each but all the vermicompost treated combination showed significant variation over the other treatments and control. As $\mathrm{K}^{+}$plays an important role in metabolic and physiological processes of plant, by affecting the enzymatic activities, which were probably enhanced on account of variation in $\mathrm{K}_{2} \mathrm{O}$ content, were resulting in increased $\mathrm{CO}_{2}$ assimilation and subsequent increase in carbohydrate and anthocyanin synthesis (Fisher and Kwong, 1961). Thus increases the colour intensity of fruits. Increase in fruit colour intensity of fruits with variation in $\mathrm{K}_{2} \mathrm{O}$ content in different sources of potassium as well as in foliar application was observed by Wojcik (2005) and Kilany and Kilany (1991) on Anna apple trees.

Effect on juice content: The results revealed that juice content of apple got significantly increased from 32.6 to 41.7 percent with different sources of potassium from $T_{1}$ to $T_{10}$. The highest juice content of 41.7 per cent was found in $T_{4}$ treatment combination while as the treatment $T_{7}$ and $T_{10}$ was statistically at par with each other but all the vermicompost treated combination showed a significant variation over all the treatment and control. Potassium uptake is expected to assist in $\mathrm{CO}_{2}$ assimilation and subsequent synthesis of carbohydrates which was probably higher on account of increased potassium fertilization. Potassium promotes fruitfulness through its enzyme activating property. It must be activating the enzymes involved in the conversion of carbohydrates to ribose sugar, which is a component of RNA (Gopalswamy, 1969) thus increase the juice content significantly. These results were in close conformity with those obtained by Kaith and Awasthi (1989), Daroshenko et al. (2005) and Wojcik (2005) while working on different cultivars of apple.

Organoleptic evaluation: The finding revealed that the effect of different sources of potassium on texture, flavour, aroma, taste and appearance of apple fruit was found to be enhanced. A stimulatory effect on development of organoleptic rating was observed in case of treatment combination of $T_{4}$ followed by $T_{7}$ and $T_{10}$ as compared to other treatments and control. The reason behind the enhancement of fruit sensory parameters was that the potassium plays an important role in metabolic and physiological processes of plant by affecting the enzymatic activities resulting in increased $\mathrm{CO}_{2}$ assimilation, subsequent increase in carbohydrate and anthocyanin synthesis and also maintains cell shape (Fisher and Kwong, 1961).

\section{Conclusion}

The significance of recommended fertilizers of different sources of potassium with foliar application along with organic manures was well recognized with respect to their effect to sustained apple crop production, soil health and maintains ecological balance. The study also concluded that treatment combination of $\mathrm{T}_{4}\left(\mathrm{RFQ}_{1}+2\right.$ foliar sprays of MOP @ 1.5\% + vermicompost @ 5 kg/ tree) is suitable for sustainable yield and quality of apple and plant nutrient to an optimum level. How- 
ever such study needs further testing under different agro-climatic condition of the valley.

\section{ACKNOWLEDGEMENTS}

The authors would like to thank and acknowledge with gratitude the Division of Soil Science and Post Harvest Technology Division, SKUAST-K, Shalimar for providing necessary laboratory facilities to carry out the research work.

\section{REFERENCES}

1. Anjum, R., Kirmani, N. A., Nageena, N., and Sameera, S. (2008). Quality of apple cv. Red delicious as influenced by potassium. Asian Journal of Soil Science. 3: 227-229.

2. Anonymous (2009). United states Department of Agriculture (USDA). National Nutrient Database For Standard Reference, Release 22.

3. Anonymous (2014). Kashmir horticulture blooms. Apple production, area under crop on rise. Greater Kashmir, $7^{\text {th }}$ May 2014.

4. AOAC (1980). Methods of Analysis. Association of Official Agriculture Chemist, Washington, USA. 484.

5. Awasthi, R.P., Bhutani, V.P., Mankotia, M.S., Chandel, J.S. and Dev, G. (1993). Potassium increases yield and quality of Santa Rosa plum. Better Crops International. 9: 22-24.

6. Barden, J.A. and Thompson, A.H. (1962). Effect of heavy annual application of potassium on Red Delicious apple trees. Proceedings of American Society of Horticulture Science. 81: 18-25.

7. Bhonsle, N.S. Pal, S.K. and Sekhon, G.S. (1992). Relationship of potassium forms and release characteristics with clay mineralogy. Geoderma. 54: 285293. DOI: $10.1016 / 0016-061$ (92)90110-S

8. Blanchar, R.W., Rehm, G. and Caldwell, A. C. (1965). Sulfur in Plant Materials by Digestion with Nitric and Perchloric Acid. Soil Science Society of America Journal. 29: 71.

9. Chand, S. and Somani, L.L. (2003). Balanced use of fertilizers, Organics and Biofertilizers in mustard. International Journal of Tropical Agriculture, 21:133-140

10.Cuming, G.A. (1980). Potassium fertilization increases yield and quality of fruits. Better Crop with Plant Food. 64: 20-21.

11.Daroshenko, T.N., Ostapendo, V.I., Byazaznova, L.G., Dubravina, I.V. and Chumakov, S.S. (2005). Formation of the quality of apple fruit under the effect of foliar application. Russian Agriculture Science. 5: 29-32.

12.Daroshenko, T.N., Ostapendo, V.I., Byazaznova, L.G., Dubravina, I.V. and Chumakov, S.S. (2005). Formation of the quality of apple fruit under the effect of foliar application. Russian Agriculture Science. 5: 29-32.

13.Dev, G., Kaith, N.S. and Awasthi, R.P. (1995). Influence of rate and method of potassium application on growth, yield, fruit quality and leaf nutrient status of apple. Journal of Potassium Research. 11: 3-4.

14.Dias, J. and Flore, J.A. (2002). Annual addition of potassium to the soil increased apple yield in Brazil. Communication in Soil Science and Plant Analysis. 15-18

15.Fisher, E.G. and Kwong, S.S. (1961). The effect of potassium fertilization on fruit quality of McIntosh apple production. American Society of Horticulture Science. 78: 16-23.

16.Gopalswamy, N. (1969). Effect of graded doses of potassium on nutrient uptake, yield and quality of grapes (Vitis vinifera L.) var. Anabe-Shahi, M. Sc. Thesis, Tamil Nadu Agri. Univ. Coimbatore (India).

17.Gomez, K.A. and Gomez, A.L. (1984). Statistical procedures for agriculture research. Willy Inter Science Publication, New York. 2.

18. Haeder, H.E. and Mengel, L.K. (1976). The influence of combined variation in light intensity and potassium nutrition on $\mathrm{CO}_{2}$ assimilation and yield formation in spring wheat. Potash Review. 54: 1-10.

19. Hafeez, A.A.A., Mohamed, A.I., Taha, N.M. and Mahaisen, S.M.A. (2010). Effect of some sources of potassium and calcium as a foliar spray on fruit quality and storability of Kelsey plums. Egypt journal of Horticulture. 37: 151-168.

20.Hansen, P. (1970). The effect of N, K, Ca and Mg on the nutrient growth and leaf development of Cox's orange apple in sand culture. Tidsskr planteavl. 74: 557-585.

21.Huang, P. (1977). Feldspars, pyroxenes and amphiboles. In: Mineral, in Soil Environment (Eds. Dixon, J.B. and Weed, S.B.), Madison. Wisconsin. American Society of Soil Science. 553-602.

22.Hudina, M., Stampar, F., Tagliarini, M., Toselli, M.M., Bertschinger, L. and Thalheimer, M. (2002). Effect of phosphorous and potassium foliar fertilization on fruit quality of pears. Proceedings of the international symposium on foliar nutrition of perennial fruit plants. Acta Horticulturae. 594: 487-493.

23.Jackson, M.L. (1973). Soil Chemical Analysis. Prentice Hall of India, Pvt. Ltd., New Delhi. 498.

24.Kaith, N.S. and Awasthi, R.P. (1989). The effect of crop load in assessing the nutrient requirements of apple trees. International Symposium on diagnosis of nutritional status of deciduous fruit orchards. Acta Horticulturae. 274.

25.Kaith, N.S. and Awasthi, R.P. (1998). Effect of potassium on growth, yield, fruit quality and nutrient status of apple Starking Delicious. Indian Journal of Horticulture. 55: 10-15.

26.Kaith, N.S., Mehta, D.K., Sharma, U. (2010). Effect of different levels of potassium on growth, yield and fruit quality of apple (Malus domestica ). Journal of Hill Agriculture. 1: 160-163.

27.Kilany, A.E. and Kilany, O.A. (1991). Effect of potassium and boron nutrients on growth, yield and fruit quality of Anna apple trees. Bulletin of Faculty of Agriculture University, Cairo. 41: 415-428.

28.Mishra, M.K., Srivastava, P.C. and Ghosh, D. (1993). Forms of potassium in relation to soil properties and clay mineralogy in some soils of Chambal command area of Rajasthan. Journal of Potassium Research. 9: 87-94.

29.Nabi B.B., Dar M.A., Peer F.A. Farooq K. (2018). Influence of nitrogen, phosphorus and potassium and their relationship with yield and quality parameters in high density apple Cv. silver spur under temperate conditions of Kashmir. International Journal of Chemical Studies.6: 2110-2113.

30.Naiema, M.S.M. (2003). Effect of different doses of nitrogen and potassium on leaf mineral content, fruit set, yield and fruit quality of apple trees grown in calcareous soil. Alexandria Journal of Agricultural 
Research. 48: 85-92.

31.Najar, G R., Akhtar, F, Singh, S.R. and Wani, J.A. (2009). Characterization and classification of apple orchards. Journal of Indian society of soil science. 57: 81-84.

32. Oberly, G.H. and Kenworthy, A.L. (1961). Effect of mineral nutrition on the occurrence of bitter pit in Northern spy apples. Proceedings of American Society of Horticulture Science. 77: 29-34.

33.Piper, C.S. (1966). Soil and plant analysis. Hans Publishers, Bombay .368.

34.Pratt, P.P. (1982). Potassium. 111: Methods of Soil Analysis. Part II (Eds. Page, A.L., Miller, R.H. and Keeney, D.R.) (American Society of Agronomy, Madison, Wisconsin, USA). 225-246.

35.Ramamoorthy, B. and Paliwal, K.V. (1976). Potassium adsorption ratio for some paddy soils in relation to their potassium availability. Soil Science, 99:236242

36.Simith, C.B. (1962). Mineral analysis of plant tissues. Plant Physiology. 13: 81-108.

37.Singh, H.R., Singh, T.A. and Singh, S. (1993). Potas- sium forms in Mollisols of Nainital Tarai. Journal of Potassium Research. 9: 8-15.

38.Singh, A.K., Sarkar, A.K., Kumar, A. and Singh, B.P. (2009). Effect of long-term use of mineral fertilizers, lime and farmyard manure on the crop yield, available plant nutrients and heavy metal status in acidic loam soil. Journal of the Indian Society of Soil Science. 57: 362-365.

39.Sparks, D.L, Page, A.L, Helmke, P.A., Leoppert, R.H., Soltanpour, P.N., Tabatabai, M.A., Johnston, C.T. and Summer, M.E. (1996). Method of Soil Analysis part 3. American Society of Agronomy Inc, Madison, Wisconsin, USA.

40.Wani, S.A., Qazi, N.A., Hakim, K.A., Bhat, M.Y., Lone, G.M., Bhat, Z.A., Mir, M.A., Khan, N.A., Singh, A., Iqbal, U. and Pratap, T. (2014). Apple Orchards of Kashmir - A Study on the State-of-Affairs. Directorate of Research SKUAST Kashmir.

41.Wójcik, P. (2005). Proceedings International Scientific Conference: Environmentally friendly fruit growing, Polli, Estonia, 7-9 September, 44-50. 